\title{
UPAYA PENANGANAN LIMBAH OLAHAN IKAN MENJADI PAKAN TERNAK UNGGAS DAN PUPUK ORGANIK CAIR
}

\author{
Komariyati \\ Fakultas Pertanian, Universitas Tanjungpura \\ email: komariyati04@yahoo.com \\ W. Padmarsari \\ Fakultas Pertanian, Universitas Tanjungpura \\ email : fx.widadi.padmarsari.s@faperta.untan.ac.id \\ Surachman \\ Fakultas Pertanian, Universitas Tanjungpura \\ email : srm_idr@yahoo.co.id
}

\begin{abstract}
Fish processed waste is an environmental problem for fish processing business in Kuala Secapah village, Mempawah Regency, West Kalimantan. This activity is an integration between the handling of fish processing waste into poultry feed and liquid organic fertilizer and efforts to improve nutrition and income of fish processors and marketers. Implementation of activities includes several stages: socialization, training, mentoring and monitoring evaluation. The indicator of the success of the activity can be seen from (1) the high entrepreneurial spirit for the fish processing and marketing group, (2) increased sales turnover through the management of production systems. The long-term goal of this activity is to become a model of eco friendly fish processing business and become a model of community development for related institutions.
\end{abstract}

Key words: fish processed waste, poultry feed, liquid organic fertilizer

\section{PENDAHULUAN}

Salah satu dari 8 (delapan) desa di Kecamatan Mempawah Hilir adalah Desa Kuala Secapah. Kecamatan Mempawah Hilir merupakan daerah pesisir, sehingga potensi perikanan laut cukup besar, seperti pekerjaan mencari ikan di laut banyak dilakukan masyarakat. Tumbuhnya pengusaha perikanan baik itu agen-agen penampung maupun pengrajin ikan asin/industri pengolahan ikan merupakan dampak dari aktifitas nelayan di Kecamatan Mempawah Hilir, termasuk Desa Kuala Secapah.

Menurut hasil wawancara dengan Kepala Desa Kuala Secapah, hasil produksi perikanan tangkap di Desa Kuala Secapah yaitu ikan (bilis, kepetek, gulama, layur, kembung, dan selar), 
udang rajungan hingga ikan jenis - jenis komersial seperti bawal, kakap, senangin, tenggiri dan tongkol. Berbagai jenis ikan tersebut dijual dalam bentuk ikan segar dan diolah menjadi ikan asin dan kerupuk ikan.

Jarak Desa Kuala Secapah dari pusat pemerintahan Kabupaten Mempawah $\pm 4 \mathrm{~km}$ dan jarak dari Kota Pontianak $\pm 80 \mathrm{Km}$, yang dapat ditempuh dengan transportasi darat. Sebagian besar penduduk Desa Kuala Secapah telah mengenyam pendidikan formal mulai dari tingkat Sekolah Dasar (SD), SLTP, SMU hingga ada juga yang menempuh ke Perguruan Tinggi dengan jenjang strata S1 maupun dengan jenjang pendidikan tingkat Akademi, tetapi masih 45\% dari seluruh penduduk yang telah mengenyam pendidikan masih berpendidikan SD. Artinya penduduk dengan tingkat pendidikan rendah masih menempati posisi terbesar dibandingkan lulusan SMP, SMP ataupun Perguruan Tinggi. (BPS Mempawah, 2016). Hal ini merupakan salah satu kendala dalam mempercepat pembangunan wilayah termasuk penyerapan informasi ataupun teknologi.

Di Desa Kuala Secapah terdapat 18 (delapan belas) Kelompok Pengolahan dan Pemasaran Ikan (Poklahsar). Poklahsar ini dibina oleh Dinas Pertanian, Ketahanan Pangan dan Perikanan (DPKP2) Kabupaten Mempawah untuk menjaga kualitas produk olahan yang berupa ikan asin dan krupuk ikan, seperti tidak menggunakan bahan pengawet dalam proses produksinya.

Limbah yang dihasilkan dari proses pengolahan ikan dapat berupa ikan yang sudah tidak layak dikonsumsi atau diolah, isi perut dan bagian lain yang tidak dikomersialkan yang dapat mencapai 10-20\% nya dari bahan mentah. Oleh karena itu dalam sehari rerata limbah dapat mencapai 5-10 kg per hari per anggota poklahsar di desa Kuala Secapah karena dalam sehari pada saat musim ikan mampu memproduksi ikan asin dan atau kerupuk ikan dengan bahan dasar $\pm 50 \mathrm{~kg}$ ikan. Limbah ikan semakin bertambah tiap harinya karena pengetahuan dan ketrampilan masyarakat yang masih terbatas dalam pemanfaatannya. Pembuangan limbah secara baik belum ada di desa Kuala Secapah, bahkan seringkali timbul permasalahan lingkungan lebih serius Karen limbah ikan dibuang ke sungai. Pemanfaatan limbah sebagai pupuk tanaman berupa pupuk organic cair dan pakan ternak unggas yang bernilai ekonomis dapat menjadi solusi penanganan limbah tersebut. Pupuk organic cair (POC) dapat diaplikasikan pada tanaman sayuran yang ada di sekitar rumah dan pakan ternak unggas dapat diberikan untuk perkembangbiakakan unggas yang selama ini telah dibudidayakan oleh masyarakat di daerah 


\section{Website : http:// jurnal.untan.ac.id/ index.php/JPLP2KM ISSN : 2620 - 4665 (print) \\ ISSN : 2620 - 4673 (online)}

pantai. Produk POC dan pakan ternak unggas dari limbah olahan ikanpun dapat dikemas dengan disertai label yang tepat sehingga akan memiliki nilai jual tinggi, selain untuk konsumsi sendiri.

Selama ini para anggota Poklahsar ikan kesulitan dalam memenuhi kebutuhan akan sayuran karena kondisi tanahnya yang sering terkena pasang air laut dan mahalnya pupuk untuk mengatasi tanah yang kurang subur. Dari kondisi ini, olahan limbah ikan menjadi pupuk organic cair yang diaplikasikan pada tanaman di pot-pot sekitar rumah dapat menjadi solusi. Demikian juga dalam pemenuhan kebutuhan protein yang belum sepenuhnya terpenuhi karena minimnya pendapatan. Padahal pemeliharaan unggas di sekitar pekarangan rumah yang telah dilakukan sebagian besar para pengolah ikan dapat menjadi solusi tepat dalam pemenuhan gizi keluarga dengan ketersediaan telur dan daging unggas. Ternak unggas yang ada hanya dipelihara sekedarnya, sehingga produksi telur dan daging belum memenuhi standar produksi yang diharapkan.

Di satu sisi, para anggota poklahsar memiliki waktu luang/kosong pada saat menunggu tahapan pengeringan pada proses pengolahan ikan. Pemanfaatan limbah olahan ikan berupa pupuk organic cair dan pakan ternak unggas menjadi alasan lebih tepat bagi para pengolah ikan untuk memanfaatkan waktu luang tersebut sehingga dapat menjadi sumber usaha pendapatan yang lain maupun untuk peningkatan gizi keluarga. Pengelolaan administrasi dan keuangan yang sehat diperlukan oleh Usaha Kecil Menengah, termasuk Kelompok Pengolahan dan Pemasaran Ikan di Desa Kuala Secapah di dalam pengusahaan olahan dan pemasaran ikan untuk peningkatan pos pendapatan dengan melakukan diversifikasi hasil. Sehingga produksi olahan ikan sesuai standar mutu dan penanganan limbahnya menjadi satu kesatuan usaha dalam mengatasi pencemaran lingkungan sekaligus peningkatan gizi dan pendapatan keluarga. 
Website : http:// jurnal.untan.ac.id/ index.php/JPLP2KM ISSN : 2620 - 4665 (print)

ISSN : 2620 - 4673 (online)

\section{METODE}

Kegiatan pengabdian masyarakat dilakukan dengan khalayak sasaran kelompok pengolahan dan pemasaran (Poklahsar) ikan di desa Kuala Secapah Kecamatan Mempawah Hilir Kabupaten Mempawah Kalimantan Barat. Sebagian besar anggota Poklahsar desa Kuala Secapah merupakan ibu-ibu yang mengolah dan memasarkan hasil olahan ikan berupa kerupuk ikan dan ikan asin.

Pelaksanaan kegiatan pengabdian masyarakat ini menggunakan metode atau tahapan-tahapan sebagai berikut : orientasi dan sosialisasi, pelatihan, pendampingan, monitoring dan evaluasi. Kegiatan tahap pertama adalah orientasi dan sosialisasi program sekaligus penyerahan alat pembuatan pakan ternak unggas dan pupuk organic cair yang merupakan hasil rakitan dari team pelaksana pengabdian masyarakat Universitas Tanjungpura. Materi sosialisasi ini tentang bagaimana pengolahan ikan yang sehat berwawasan lingkungan, pentingnya penanganan limbah pada usaha olahan ikan dan alternatif pemanfaatannya sebagai produk pupuk organic cair dan pakan ternak unggas, perencanaan bisnis, pengemasan dan pelabelan dan pentingnya manajemen internal dan eksternal melalui pembukuan usaha yang baik dan benar.

Tahapan kegiatan yang ke 2 (dua) adalah pelatihan dan pendampingan. Kegiatan ini meliputi introduksi teknologi pembuatan pakan ternak unggas dan pupuk organic cair dari limbah olahan ikan terhadap para anggota poklahsar, pengemasan dan pelabelan produk-produk alternative dari limbah olahan ikan tersebut, penyusunan rencana usaha serta perbaikan sistim pengelolaan internal dan ekternal melalui pembukuan usaha yang baik dan benar.

Tahapan selanjutnya adalah monitoring dan evaluasi. Indikator-indikator sebagai tolok ukur keberhasilan kegiatan pada tahap monitoring dan evaluasi, sebagai berikut : 1) Poklahsar dapat menghasilkan produk pupuk organic cair dari limbah olahan ikan yang dikemas ukuran 1 liter sebanyak 20 buah dengan harga Rp. 20.000,- 2) Poklahsar dapat menghasilkan pakan ternak unggas, yang dapat dimanfaatkan sendiri ataupun dijual 3) Anggota Poklahsar mampu melakukan administrasi/pembukuan usaha secara sederhana 


\section{HASIL DAN PEMBAHASAN}

\subsection{ORIENTASI DAN SOSIALISASI}

Sosialisasi program dan penyerahan alat berupa mesin penepung limbah ikan dan mesin pembuatan pellet pakan ternak unggas serta seperangkat alat pembuatan pupuk organic cair terhadap poklahsar desa Kuala Secapah Kecamatan Mempawah Hilir Kabupaten Mempawah dilaksanakan pada tanggal 03 Oktober 2017. Sebelum sosialisasi tim pelaksana telah melakukan orientasi lapangan sekaligus koordinasi di kantor desa Kuala Secapah dan melakukan diskusi secara mendalam tentang teknis pelaksanaan kegiatan dengan harapan manfaat kegiatan menjadi optimal. Hasil diskusi dengan perangkat dan tokoh-tokoh desa menyatakan bahwa kegiatan pengabdian masyarakat berupa diseminasi produk teknologi pakan ternak unggas dan pupuk organic cair akan didukung oleh perangkat dan tokoh-tokoh masyarakat desa Kuala Secapah. Berdasarkan kesepakatan dengan perangkat dan tokoh-tokoh masyarakat desa, maka kegiatan pengabdian masyarakat berupa diseminasi teknologi pengelolaan limbah olahan ini terbagi menjadi beberapa tahap, yaitu sosialisasi program kegiatan, pelatihan dan pendampingan serta monitoring evaluasi dengan waktu-waktu serta peserta pelatihan tertentu.

Materi sosialisasi ini tentang bagaimana pengolahan ikan yang sehat berwawasan lingkungan, pentingnya penanganan limbah pada usaha olahan ikan dan alternatif pemanfaatannya sebagai produk pupuk organic cair dan pakan ternak unggas, perencanaan bisnis, pengemasan dan pelabelan serta pentingnya manajemen internal dan eksternal melalui pembukuan usaha yang baik dan benar. Kegiatan sosialisasi tentang bagaimana pengolahan ikan yang sehat berwawasan lingkungan, pentingnya penanganan limbah pada usaha olahan ikan dan alternatif pemanfaatannya sebagai produk pupuk organic cair dan pakan ternak unggas telah menambah pengetahuan para anggota poklahsar di desa Kuala Secapah sehingga memiliki persepsi positif tentang usaha olahan ikan ramah lingkungan. Anggota poklahsar yang mengikuti sosialisasi sebanyak 75\% dari total anggota kelompok yang hadir telah mengetahui dan memahami materi sosialisasi. Hal tersebut dibuktikan dengan 30 orang anggota poklahsar yang hadir, sekitar 23 orang mampu menjawab dengan baik pertanyaan-pertanyaan yang dituangkan dalam kuesioner dan tanya jawab yang berlangsung pada saat sosialisasi tentang materi tersebut.Sikap dan tindakan positif akan timbul jika pengetahuan dan persepsi anggota poklahsar positif. Dengan 


\section{Website : http:// jurnal.untan.ac.id/ index.php/JPLP2KM ISSN : 2620 - 4665 (print) \\ ISSN : 2620 - 4673 (online)}

adanya pengetahuan dan persepsi yang positif, diharapkan para anggota poklahsar tahu, mau dan mampu melakukan usaha pengolahan ikan yang ramah lingkungan.

Materi sosialisasi tentang perencanaan bisnis, pengemasan dan pelabelan serta pentingnya manajemen internal dan eksternal melalui pembukuan usaha yang baik dan benar terhadap usaha olahan ikan yang dijalankan selama ini dan terhadap produk-produk alternatif olahan limbah ikan berupa pakan ternak unggas dan pupuk organic cair. Gagalnya calon wirausaha atau pengusaha di awal usaha mereka adalah akibat tidak mampu merancang perencanaan bisnis (business plan) yang baik. Akibatnya wirausaha baru tersebut ketika memasuki dunia bisnis, banyak hal yang tak terduga muncul dan tak tahu apa yang harus dilakukan (Rhenald Kasali, 2010). Oleh karena itu materi perencanaan bisnis adalah penting karena materi sosialisasi ini telah membuka wawasan para anggota poklahsar bagaimana pentingnya merencanakan sebuah usaha, walaupun dengan cara yang sederhana.

Pengemasan dan pelabelan bertujuan untuk meningkatkan nilai tambah produk. Peran kemasan tidak hanya untuk menginformasikan konsumen tentang produk tersebut, namun juga harus dapat menarik perhatian konsumen. Berdasarkan tanya jawab dan diskusi selama proses sosialisasi, pentingnya perencanaan bisnis sekaligus manajemen internal dan eksternal serta pengemasan dan pelabelan terhadap produk-produk alternative dari limbah olahan ikan berupa ikan asin dan krupuk ikan telah cukup dipahami oleh anggota poklahsar yang hadir dalam sosialisasi tersebut. Kurang lebih 50 persen dari anggota poklahsar yang hadir secara antusias mengajukan pertanyaan maupun menjawab pertanyaan yang diajukan oleh narasumber. Dengan pengetahuan tentang materi ini, diharapkan anggota poklahsar nantinya mau dan mampu dalam menerapkan materi tersebut. 


\subsection{PELATIHAN DAN PENDAMPINGAN}

Limbah yang dominan dari usaha perikanan termasuk usaha olahan ikan adalah limbah dan cemaran yang berupa limbah cair yang membusuk sehingga menghasilkan bau amis/busuk yang sangat menganggu estetika lingkungan (Ditjen Perikanan, 2007), sedangkan menurut Dewantoro (2003) limbah yang dihasilkan dari industri pengolahan hasil perikanan umumnya dapat di golongkan menjadi 3 kelompok yaitu : limbah padat berupa limbah padat basah dan limbah padat kering, limbah cair dan limbah hasil samping. Menurut Dewantoro(2003) komposisi limbah padat usaha perikanan terdiri dari: (1) daging merah sebanyak 25\%, (2) Bone (kepala, duri, ekor) sebanyak 55\%, (3) Isi perut (jerohan dan darah) sebanyak 15\% dan (4) Karton, plastik, dan lainlain sebanyak 5\%. Limbah berupa daging merah, bone (kepala, duri, ekor), isi perut, dan karton atau plastik tersebut akan menimbulkan masalah yang serius terhadap lingkungan apabila tidak dikelola dengan baik. Limbah cair dari hasil perikanan dapat berupa sisa cucian ikan/udang, darah dan lendir ikan, yang banyak mengandung minyak ikan sehingga menimbulkan bau amis yang menyengat. Limbah cair ini merupakan limbah yang dominan dari usaha perikanan karena selama proses, membutuhkan air dalam jumlah yang cukup banyak. Limbah cair juga berasal dari sanitasi dan toilet pada lokasi usaha tersebut (Ginting, 1992).

Pelatihan penerapan teknologi penanganan limbah pengolahan ikan menjadi pakan ternak merupakan upaya penanganan limbah olahan ikan yang selama ini menjadi masalah yang belum terpecahkan di masyarakat desa Kuala Secapah. Pelatihan diawali dengan mempersiapkan alat-alat dan bahan serta brosur sebagai panduan teknis praktis bagi para anggota poklahsar agar cepat mengerti dan terampil dalam menerapkan teknologi tersebut. Kerjasama yang sangat baik dalam pelaksanaan pelatihan ditandai dengan sebagian peserta menghancurkan limbah olahan ikan ke dalam mesin penepung dan sebagian peserta menimbang bahan-bahan, seperti dedak, jagung dan tepung tapioka dengan komposisi tertentu dan kemudian dicampur dengan tepung ikan untuk dibuat adonan. Setelah menjadi adonan, bahan-bahan tersebut dimasukkan dalam mesin penggiling lagi sehingga terbentuk pakan ternak unggas berupa pellet yang siap dikeringkan di bawah sinar matahari.

Mesin penepung sebagai alat menghancurkan limbah ikan kering yang diserahkan ke para anggota poklahsar ikan merupakan rakitan dari tim pelaksana pengabdian yang terdiri dari: bagian mesin stater, bagian penggiling, dan rangka, pully serta V-belt. Demikian juga alat pembuat pellet pakan ternak unggas terdiri dari mesin starter, mesin pellet ikan dan rangka, 


\section{Website : http://jurnal.untan.ac.id/ index.php/JPLP2KM}

ISSN : 2620 - 4665 (print)

ISSN : 2620 - 4673 (online)

pully serta V-belt. Diperkirakan mesin ini memiliki kemampuan mengolah seluruh limbah ikan yang dihasilkan anggota poklahsar ikan yang ikut dalam pelatihan.

Proses pelatihan penerapan teknologi penanganan limbah pengolahan ikan menjadi pakan ternak unggas terlaksana dengan lancar. Peserta pelatihan berjumlah 35 orang secara sungguhsungguh mengikuti kegiatan pelatihan yang bertempat di dalam dan teras gedung pertemuan kantor desa Kuala Secapah. Adanya kesesuaian ternak unggas di daerah pantai dan melimpahnya limbah olahan ikan telah mendorong mereka untuk dapat membuat sendiri pakan ternak unggas dan sekaligus mengaplikasikan pakan ternak tersebut untuk mendukung keberhasilan budidaya ternak unggasnya.

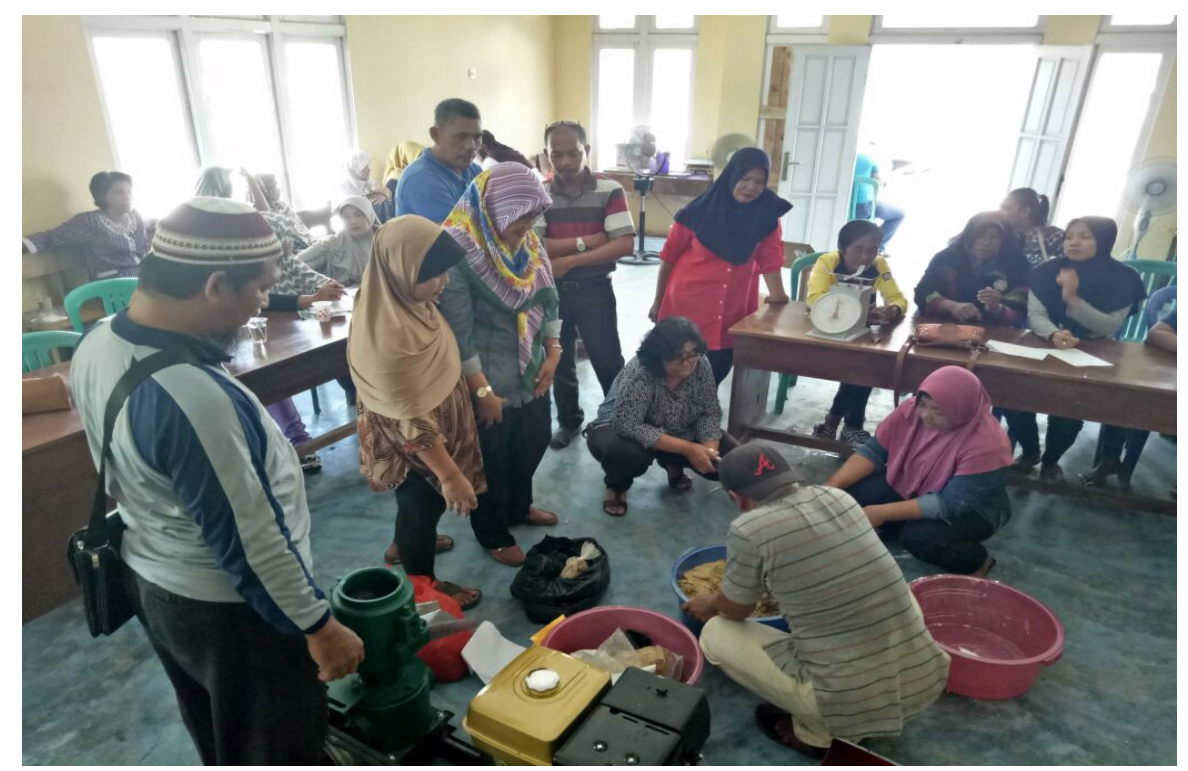

Gambar 1. Pelatihan Pembuatan Pakan Ternak Unggas dari Limbah Olahan Ikan 


\section{Website : http:// jurnal.untan.ac.id/ index.php/JPLP2KM ISSN : 2620 - 4665 (print) ISSN : 2620 - 4673 (online)}

Pendampingan terhadap para anggota poklahsar ikan dilakukan setelah 5 (ima) hari dari pelatihan alih teknologi pembuatan pakan ternak unggas. Berdasarkan pengamatan dan hasil kuesioner yang dibagi kepada 20 orang peserta pelatihan, ternyata $60 \%$ dari peserta pelatihan yang telah secara jelas bisa menjawab tentang cara-cara pembuatan pakan ternak unggas dari limbah olahan ikan dan yang mampu mengoperasikan alat hanya 5 (lima) orang.

Pelathan dalam rangka diseminasi teknologi pembuatan pupuk organic cair dilaksanakan 10 Oktober 2017. Anggota kelompok poklahsar sangat antusia dalam mengikuti pelatihan ini, terbukti dengan kemauan para anggota dalam ikut andil setiap tahapan pelatihan serta adanya tanya jawab yang berlangsung pada saat pelatihan.

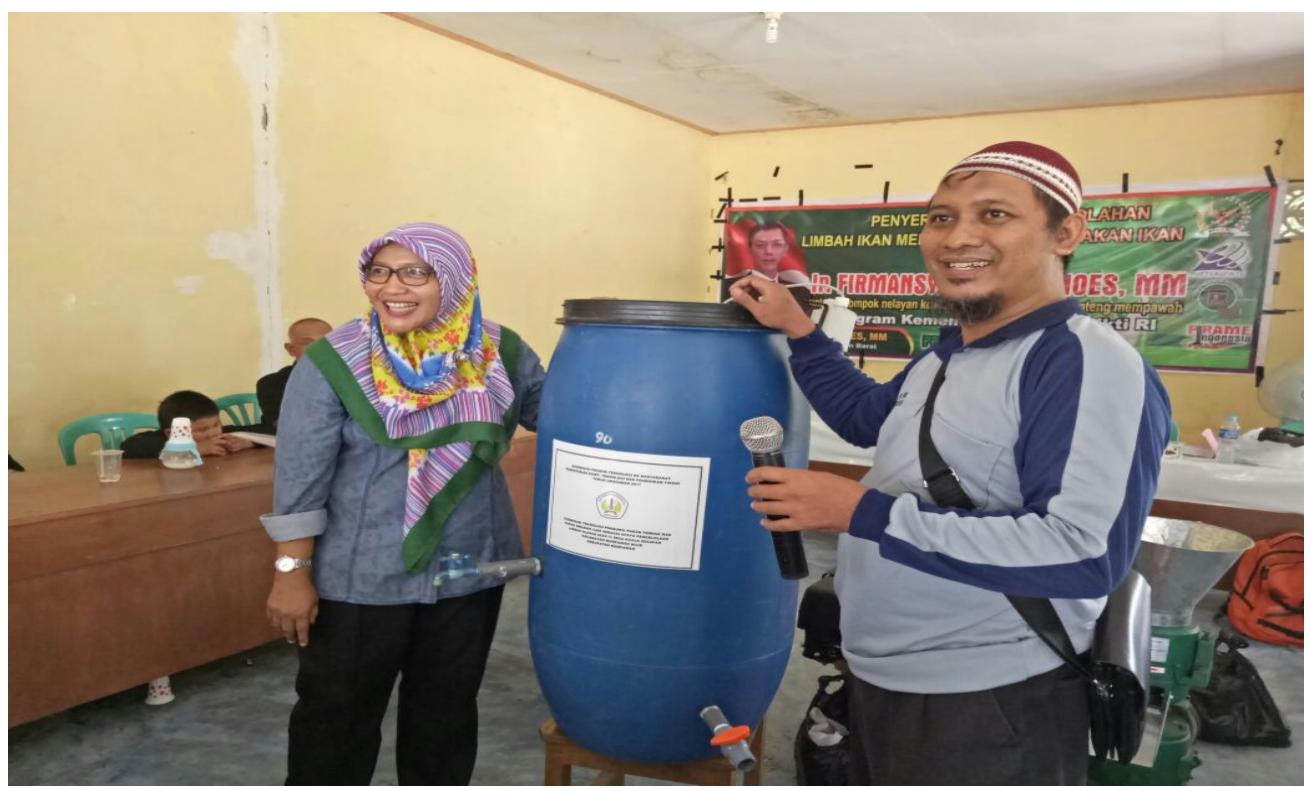

Gambar 2. Pelatihan Pembuatan Pupuk Organik Cair dari limbah olahan ikan

Pendampingan terhadap tindak lanjut dari pelatihan tentang pembuatan pupuk organic cair dilakukan setelah 5 (lima) hari pelatihan untuk melihat kemampuan para anggota poklahsar dalam mengaplikasikan teknologi yang telah diintroduksikan. Pada pendampingan terlihat, para anggota poklahsar ikan yang sangat antusias dengan introduksi teknologi ini menunjukkan kemampuan dalam menjawab pertanyaan-pertanyaan berkisar tentang manfaat dan urutan-urutan proses pembuatan pupuk ini sekaligus rencana pemanfaatannyan dalam memupuk tanaman sayuran yang akan ditanam melalui pot-pot dan barang bekas di sekitar rumahnya. Dari 20 orang yang diwawancarai, 70\% telah mau dan mampu dalam menerapkan teknologi pembuatan pupuk organic cair dari limbah olahan ikan. 


\section{Website : http:// jurnal.untan.ac.id/ index.php/JPLP2KM ISSN : 2620 - 4665 (print) \\ ISSN : 2620 - 4673 (online)}

Pelatihan dan pendampingan perencanaan bisnis produk pakan ternak unggas dan pupuk organic cair dilakukan juga terhadap para anggota poklahsar sekaligus packaging dan labeling. Materi pelatihan perencanaan bisnis ini dimulai dengan menuliskan kembali data usaha, seperti nama usaha, bidang usaha, jenis produkljasa, alamat usaha, nomor telepon, mulai berdiri, dan sebagainya. Kemudian peserta diajak untuk menghitung kebutuhan bahan habis pakai, peralatan dan sebagainya. Pembukuan yang sederhana menjadikan pebisnis akan lebih teliti dan mengetahui keuntungan dan kerugian usaha yang dijalani (Anonim, 2016b). Perencanaan usaha atau bisnis, terutama pembuatan administrasi pembukuan masih perlu pendampingan secara intensif. Hal ini terlihat pada saat pendampingan, daya serap peserta pelatihan hanya mencapai $40 \%$.

Pelatihan dan pendampingan dengan materi pengemasan dan pelabelan telah menghasilkan desain kemasan produk pupuk cair organic dan pakan ternak unggas untuk pemasaran yang diduga menjadi daya tarik pembeli sehingga mampu mendongkrak harga jualnya. Menurut Cenadi, C.S. (2000), kemasan merupakan "pemicu" karena fungsinya langsung berhadapan dengan konsumen. Kemasan harus dapat memberikan impresi spontan yang mempengaruhi tindakan positif konsumen di tempat penjual. Hasil pelatihan dan pendampingan menunjukkan bahwa anggota poklahsar yang mengikuti pelatihan ini telah memahami fungsi dari pengemasan dan pelabelan terhadap produk alternative dari limbah olahan ikan.

Secara keseluruhan, kendala yang ditemukan pada waktu pelatihan adalah peserta pelatihan relatif lambat dalam memahami dan menerapkan teknologi pemanfaatan limbah olahan ikan, perencanaan bisnis maupun melakukan pembukuan usaha secara sederhana. Diduga faktor pendidikan peserta pelatihan yang relatif rendah (rata- rata lulusan SD) menjadi faktor penyebab mereka mengalami kesulitan dalam aplikasi pelatihan tersebut. 


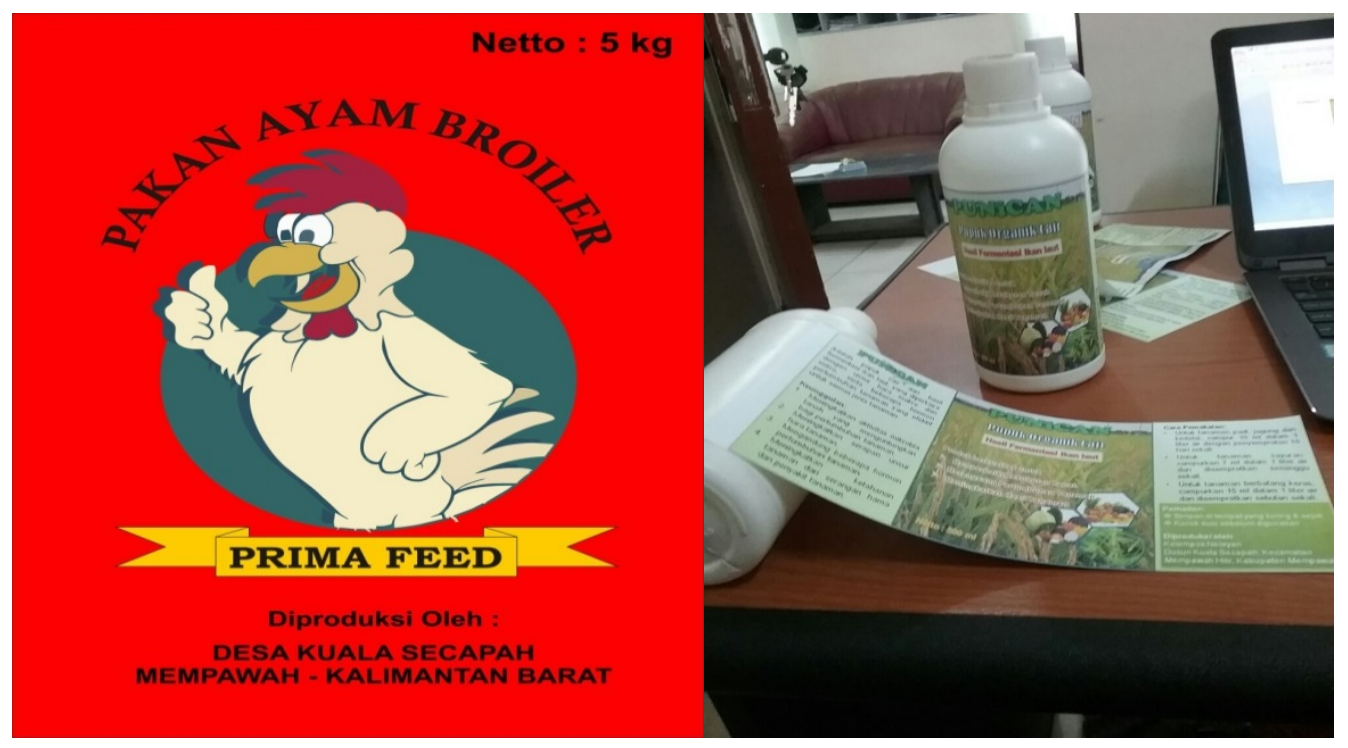

Gambar 3. Desaian Kemasan Produk Alternatif Limbah Olahan Ikan

\subsection{MONITORING DAN EVALUASI}

Monitoring dan evaluasi dilakukan setelah selesai tahapan pelatihan dan pendampingan dalam introduksi penerapan teknologi. Evaluasi dilakukan secara berkala. Berdasarkan hasil monitoring dan evaluasi inilah, tim pelaksana dapat mengetahui kekurangan dan kesalahan dari proses sosialisasi, pelatihan dan pendampingan sehingga berdampak kurang berhasilnya introduksi teknologi terhadap para anggota poklahsar. Monitoring dan evaluasi juga menjadi upaya membangkitkan dan meningkatkan motivasi para anggota poklahsar dalam meningkatkan kemauan dan kemampuannya mengintroduksi teknologi yang telah diterima selama pelatihan melalui penghargaan sederhana dan kata-kata pujian yang membangkitkan semangat para anggota poklahsar yang telah mampu menerapkan teknologi.

Berdasarkan indicator yang telah ditetapkan sebagai tolok ukur keberhasilan seluruh kegiatan, maka hasil monitoring dan evaluasi menunjukkan bahwa : 1) Poklahsar baru dapat menghasilkan produk pupuk organic cair dari limbah olahan ikan secara bersama-sama yang digunakan untuk pemupukan tanaman sendiri dan belum berorientasi untuk dijual 2) Poklahsar dapat menghasilkan pakan ternak unggas, tetapi masih sebatas untuk dimanfaatkan sendiri 3) Sekitar 40\% anggota poklahsar ikan yang mampu melakukan administrasi/pembukuan usaha secara sederhana 


\section{SIMPULAN DAN REKOMENDASI}

\section{SIMPULAN}

Simpulan dari kegiatan pengabdian masyarakat dengan khalayak sasaran anggota-anggota kelompok pengolahan dan pemasaran ikan desa Kuala Secapah adalah 1) Solusi penanganan limbah olahan ikan bagi para anggota kelompok poklahsar ikan di desa Kuala Secapah adalah penerapan teknologi pembuatan pupuk cair dan kpakan ternak unggas dan pupuk organic cair dari limbah olahan ikan 2) Aplikasi produk alternative dari limbah olahan ikan berupa pakan ternak unggas dan pupuk organic cair terhadap ternak unggas dan tanaman dalam pot di sekitar rumah anggota poklahsar ikan dapat meningkatkan gizi keluarga dan pendapatan secara tidak langsung.

\section{REMOKENDASI}

Kegiatan pendampingan terhadap anggota poklahsar harus dilakukan secara lebih intensif mengingat nilai manfaat teknologi yang diintroduksikan sangat tinggi. Selain itu, perlu kegiatan serupa pada tahun-tahun berikutnya di kecamatan Mempawah Hilir secara luas dan masyarakat sekitarnya, sehingga menjadi kegiatan yang berkesinambungan.

\section{DAFTAR PUSTAKA}

Anonim. 2016. Pembukuan Keuangan Sederhana Memulai Usaha Kecil. https://www.akun.biz/tipsbisnis/pembukuan-keuangan-usahal. (Diakses tanggal 19 Februari 2017).

Badan Pusat Statistik. 2016. Mempawah Hilir dalam Angka Tahun 2015. BPS Kubu Raya, Pontianak.

Cenadi, C. S. 2000. Peranan Desain Kemasan dalam Dunia Pemasaran. Jurnal Nirmana Vol. 2. No.1 Edisi Januari 2000: 92-103.

Dewantoro, R.A. 2003. Proses pengolahan limbah cair pada usaha pembekuan ikan di PT. ILUFAPasuruan Jawa Timur. Karya IImiah Praktek Akhir, Akademi Perikanan Sidoarjo, DKP.

Ditjen Perikanan Budidaya (Tekno Ikan). 2007. "Pemanfaatan Limbah Ikan Sebagai Bahan Baku Pupuk Organik", DKP.

Ginting, P. 1992. Mencegah dan mengendalikan pencemaran industry. Edesi 1. Jakarta: Pustaka Sinar Harapan

Kasali R. 2010. Wirausaha Muda Mandiri (Independent Young Entrepreneur). Gramedia Pustaka Utama. Jakarta. 